\title{
Treatments for people who use anabolic androgenic steroids: a scoping review
}

\author{
Geoff Bates ${ }^{*}{ }^{*}$, Marie-Claire Van Hout', Joseph Tay Wee Teck ${ }^{2}$ and Jim McVeigh ${ }^{3}$
}

\begin{abstract}
Background: A growing body of evidence suggests that anabolic androgenic steroids (AAS) are used globally by a diverse population with varying motivations. Evidence has increased greatly in recent years to support understanding of this form of substance use and the associated health harms, but there remains little evidence regarding interventions to support cessation and treat the consequences of use. In this scoping review, we identify and describe what is known about interventions that aim to support and achieve cessation of AAS, and treat and prevent associated health problems.

Methods: A comprehensive search strategy was developed in four bibliographic databases, supported by an iterative citation searching process to identify eligible studies. Studies of any psychological or medical treatment interventions delivered in response to non-prescribed use of AAS or an associated harm in any setting were eligible.

Results: In total, 109 eligible studies were identified, which included case reports representing a diverse range of disciplines and sources. Studies predominantly focussed on treatments for harms associated with AAS use, with scant evidence on interventions to support cessation of AAS use or responding to dependence. The types of conditions requiring treatment included psychiatric, neuroendocrine, hepatic, kidney, cardiovascular, musculoskeletal and infectious. There was limited evidence of engagement with users or delivery of psychosocial interventions as part of treatment for any condition, and of harm reduction interventions initiated alongside, or following, treatment. Findings were limited throughout by the case report study designs and limited information was provided.

Conclusion: This scoping review indicates that while a range of case reports describe treatments provided to AAS users, there is scarce evidence on treating dependence, managing withdrawal, or initiating behaviour change in users in any settings. Evidence is urgently required to support the development of effective services for users and of evidence-based guidance and interventions to respond to users in a range of healthcare settings. More consistent reporting in articles of whether engagement or assessment relating to AAS was initiated, and publication within broader health- or drug-related journals, will support development of the evidence base.
\end{abstract}

Keywords: Anabolic androgenic steroids, Drug treatment, Health care, Dependence, Behaviour change

\section{Introduction}

Human enhancement drug use differs from other forms of drug use by virtue of the motivation or purpose of their use. Typically, they are not consumed either for a treatment of an illness or injury nor for instant gratification through their psychoactive properties. Instead, their function is an attempt to change an individual's appearance or improve a skill, ability or activity $[1,2]$. Characterised by man's endeavour to gain an advantage over his competitor, their

\footnotetext{
* Correspondence: g.bates@ljmu.ac.uk

${ }^{1}$ Public Health Institute, Liverpool John Moores University, Liverpool, England Full list of author information is available at the end of the article
}

usage is by no means a new phenomenon, featured in social, ritual and sporting contexts throughout recorded history. Attempts to classify enhancement drugs have resulted in the six broad categories of drugs to increase lean muscle mass, to suppress appetite or reduce weight, to change the appearance of the hair or skin, to increase sexual desire or enhance performance, to improve cognitive function and to enhance mood or social interaction. Over the past 30 years, there has been growing media, policy and academic interest in this form of drug use, in particular the classification of drugs used to enhance musculature size and strength. Most notable within this category are the

(c) The Author(s). 2019 Open Access This article is distributed under the terms of the Creative Commons Attribution 4.0 International License (http://creativecommons.org/licenses/by/4.0/), which permits unrestricted use, distribution, and 
anabolic androgenic steroids (AAS) and their associated drugs [3-6]. Also included in this classification are a range of other hormones [7-11] including human growth hormone $[12,13]$ and insulin $[7,14]$.

While AAS doping remains a concern for sport, both at elite and recreational levels [15-17], the wider societal impact is now apparent $[4,18,19]$. Although prevalence estimates of clandestine behaviours such as AAS are notoriously difficult, a growing body of evidence has indicated that while well established in North America, northern Europe and Australia, there are concerns across the globe $[6,19]$.

In recent years, research has provided a more nuanced understanding of AAS use in relation to the diverse characteristics and motivations of users [20-27], together with knowledge of the variety and patterns of drug use from both academic studies [28-34] and other sources [35]. Extensive research and comprehensive reviews have provided details of the identified adverse health conditions experienced by users of these durgs [36], while new research has identified new and concerning health risks $[37,38]$ and the potential for transmission of blood-borne viruses [20, 29, 39-43].

A body of research has discussed the risk of developing AAS dependence and it is estimated that up to 30\% of AAS users may develop dependence, characterised by the simultaneous use of multiple AAS in large doses over long periods of time [36, 44]. While AAS are not explicitly recognised in the Diagnostic and statistical manual of mental disorders (DSM 5) as one of nine classes of drugs [45], they may be considered under the tenth 'other (or unknown) substance' class. The DSM 5 determines the severity of a substance use disorder from mild to severe according to the presence of up to 11 criteria. It is argued that while there are differences between AAS and psychoactive drugs dependence, such as that AAS are typically used over a period of weeks and months to increase muscularity rather than to achieve a 'high' in the short-term, these criteria are still highly applicable to AAS dependence [46]. Criteria such as tolerance, withdrawal, use of the substance in larger amounts, unsuccessful attempts to reduce or stop using the substance, and time spent on activity related to the substance use have all been identified as features of AAS dependence $[44,46]$. A number of hypotheses to explain AAS dependence have been put forward $[47,48]$ and recommendations for treating what has been described as steroid 'abuse' or dependence have long been proposed [49-51].

Recent recommendations to treat steroid dependence include a staged discontinuation, managing withdrawal symptoms, maintaining abstinence and attenuating complications of chronic use [51-53]. Long-term use of AAS at high doses may lead to the development of a range of withdrawal symptoms following cessation, including depression, insomnia, suicidal ideation and fatigue, which may persist for many months $[47,51,54]$. Withdrawal is characterised by psychiatric and neuroendocrine symptoms, with the user ultimately re-initiating AAS to alleviate or avoid their onset. Supporting discontinuation may require a multidisciplinary approach with input from health professionals such as a GP, addiction specialist, psychiatrist and endocrinologist [53]. Swedish guidelines for diagnosing and treating AAS 'abuse' [55] include advice around psychosocial treatments, such as cognitive behavioural therapy, counselling group therapy and motivational interviewing. These therapies address the user's preoccupation with enhancing their muscularity, their experiences of past bullying or violence, and resulting self-esteem and confidence issues. Brower (2009) believes that these entrenched psychological issues should be addressed once acute withdrawal is resolved as part of successful treatment [51]. Muscle dysmorphia and associated drive for muscularity [56-58] may be risk factors for both initiating and continuing AAS use, and potentially dependence [52]. It may be necessary to identify and address such disorders through counselling or psychotherapies as part of AAS treatment to reduce likelihood of re-initiation [53].

There has been a fourfold increase in the number of English language academic papers published between 1995 and 2015 [59]. However, there remains scant evidence in relation to effective policy and practice within the topic. While we have a greater understanding of the environmental influences and risk factors for use [17, 60-62], there are few robust findings to support the effective prevention of AAS use. Little progress has been made in answering the fundamental questions of how do we make AAS less attractive and how do we make these drugs less accessible to those at risk of initiating use [63-66].

Tensions between some AAS users and the medical community are well documented [26, 67-69] and long established [70], predating anti-doping or legislative control in most countries. Although psychological harm and the potential demand for interventions to address dependence are also well recognised [71-75] and diagnostic tools available $[52,76]$, available services are few and far between. Harm reduction programmes, in the form of needle and syringe programmes (NSP), have clearly been successful in engaging AAS users in Australia [42, 43, 77, 78] and, in particular, the United Kingdom [5, 30, 79, 80]. However, even where uptake of service is high, substantial numbers of AAS users do not access these services [26, 68, 80, 81]. Policy guidance regarding the delivery of harm reduction services for AAS users, centred around NSP provision, is in place in the United Kingdom [82, 83], with its 
importance recognised in National Drug Strategy and Treatment guidelines [84, 85]. While these guidelines are based on well-established principles of treatment engagement and harm reduction, there is an urgent need to identify where we have evidence to support specific interventions and where the evidence gaps remain.

\section{Aims}

The overall aim of this review was to identify and describe what is known about psychosocial and medical interventions that aim to support and achieve cessation of AAS, and treat and prevent associated health consequences. Specifically, the review aimed to identify:

1. What studies have examined the implementation and impact of interventions to support ASS cessation, and manage the health consequences related to cessation?

2. What studies have examined the implementation and impact of interventions to treat the harms or side effects associated with AAS use?

3. What are the implications of these findings, and what are the gaps in the evidence base that research in this area needs to address?

\section{Methodology}

The review was undertaken following Arksey and O'Malley's guidance for scoping reviews, which informed the development of review methods and write-up of methods and findings [86].

\section{Inclusion and exclusion criteria}

Studies were eligible that included males or females with current or discontinued use of AAS alone, or AAS use alongside other substances. Use for any reason (for example, strength or sporting enhancement, aesthetic reasons) was acceptable with the exception of where AAS were prescribed or taken as part of a treatment regimen or in a controlled medical setting. Studies of any psychosocial or medical treatment interventions were eligible, including those that aimed to support individuals to discontinue AAS use or to treat the health consequences of current or past use. This included, but was not restricted to, treating AAS withdrawal, physical or psychological dependence, injuries, acute conditions, chronic conditions, side effects and blood-borne viruses. Studies that did not provide a description of the treatment given or those that did not describe any outcome following treatment at any follow-up time were excluded. Interventions that took place in any setting were eligible, including, but not restricted to, primary and secondary care, community settings such as drugs misuse services, NSPs and AAS clinics, sport and fitness environments, and prisons.
All types of study designs were considered due to the anticipated lack of high-quality controlled trials. Articles published in English were eligible with no date restrictions.

\section{Search strategy}

Initially, a comprehensive search was carried out in four bibliographic databases (Medline, PsycINFO, Sports Discus and the Social Sciences Citation Index) in January 2018. A search strategy was developed initially in Medline and adapted for the other databases. The full Medline search is provided in Additional file 2.

The reference lists of all identified papers were screened to identify potentially eligible studies. Forward citation searches for included articles were executed in PubMed and the identified studies were assessed against the review inclusion criteria. This iterative process continued for all articles identified through these steps. Due to the nature of the evidence base, with studies likely to cover a broad range of topics and to be published in a wide variety of sources, these additional searches were expected to be important to identify relevant literature. Initially, titles and abstracts for all articles identified were reviewed against the inclusion criteria by one reviewer. A sample of $10 \%$ was independently reviewed by a second reviewer. The full texts for all articles included at this stage were retrieved and subjected to further screening against inclusion criteria.

\section{Data extraction and synthesis}

The relevant characteristics of identified studies were extracted into structured tables. This included population characteristics and details of their AAS use, the symptoms requiring treatment or reasons for seeking help, diagnosis, details of the treatment given and the outcomes of this treatment. Studies were grouped by the types of harms identified in Pope and colleagues' review of the harms associated with AAS use [36]. A formal assessment of study quality was not undertaken, as this step is not recommended for scoping reviews [86]. However, comments on the overall nature, strengths and limitations of the evidence base are provided alongside discussion of review findings.

\section{Results}

\section{Identification of studies}

Database searching identified 3,684 articles. Following screening of article title and abstracts against review inclusion criteria, full-text articles were accessed for 76 articles and these were again reviewed against the inclusion criteria. An additional 64 studies were identified through checking the reference lists and citations of the included articles. These were screened in the same manner. Following full-text screening, 46 articles were 
excluded, predominantly because no treatments were reported. The reasons for exclusion at this stage are reported in Fig. 1.

\section{Summary of findings}

In total, 109 studies met the review inclusion criteria. Summaries of the included studies are provided in Table 1, grouped by the type of condition that required treatment. The studies were carried out in 28 countries, most prominently the USA $(n=33)$ and the UK $(n=$ $21)$. One study followed a retrospective chart review design with the others case report $(n=94)$ or case series $(n=14)$ designs. With the lack of any controlled studies, it was difficult to draw conclusions relating to the effectiveness of any treatments provided. Additionally, there were substantial variations across studies in the depth of reporting about participants, settings, condition requiring treatment, the treatments provided and outcomes. The identified studies were published in sources representing a diverse range of disciplines.

Across the included studies, all participants were male. They included a wide range of ages, with the majority in their 20s and 30s, and represented a broad range of experience using AAS from recent initiators to long-term use. Participants' motivations and history were not reported in a consistent manner to understand factors driving AAS use, but they were frequently described as participating in bodybuilding or weight-lifting activities. The types of conditions requiring treatment included psychiatric $(n=12)$, neuroendocrine $(n=11)$, hepatic $(n$
= 25), kidney $(n=6)$, cardiovascular $(n=26)$, musculoskeletal $(n=13)$ and infectious $(n=7)$. A further eight studies were categorised as 'other' disorders. In a small number of studies, participants were diagnosed with multiple conditions, but they have been grouped by the primary diagnosis.

Further details on participants' AAS use, conditions requiring treatment, the treatments provided and outcomes are provided in Additional file 1.

\section{Treatment to support AAS cessation}

Four studies reported abstinence-focussed interventions following a diagnosis of AAS dependence. In two cases, patients participated briefly in a drug treatment programme $[88,97]$ before withdrawing. In one, the patient received medication and psychosocial interventions to manage AAS and opioid withdrawal [93] and withdrawal symptoms abated over time. Detail on the nature of these treatments was not provided. In the remaining study, the patient received medication for a short period before deciding to resume their AAS use due to withdrawal symptoms [98]. There was no evidence identified here, however, regarding psychosocial interventions that have sought to address any associated psychological disorders amongst users seeking treatment for their AAS use or any other condition. Additionally, no evidence was identified on approaches to reduce risk of relapse by developing social support systems, improving self-confidence or managing stress,

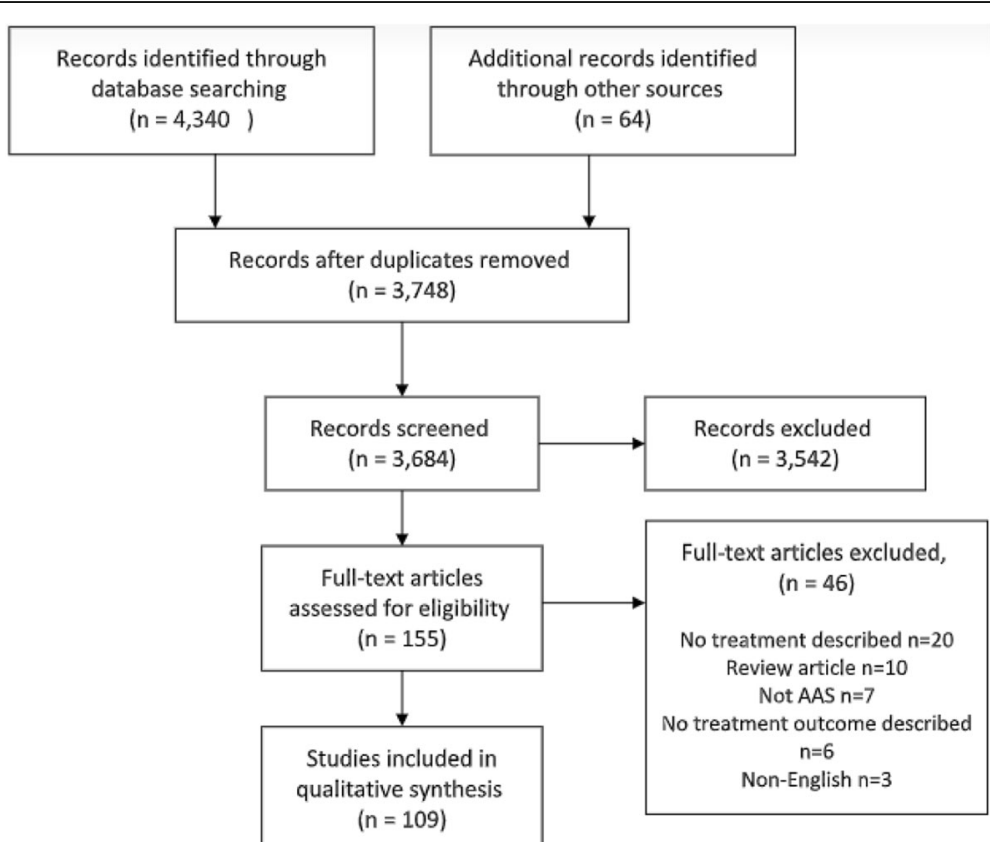

Fig. 1 Flow of studies through the review 
Table 1 Summary of included studies

\begin{tabular}{|c|c|c|c|c|}
\hline $\begin{array}{l}\text { Reference } \\
\text { no. }\end{array}$ & Country & $\begin{array}{l}\text { Study } \\
\text { design }\end{array}$ & Diagnosis & Treatment approach \\
\hline \multicolumn{5}{|c|}{ Psychiatric $(n=12)$} \\
\hline [87] & USA & CS & Depression & Medical therapy \\
\hline [88] & USA & $C R$ & Substance dependence & Drug treatment programme participation \\
\hline [89] & Canada & $C R$ & Depressed mood with anxiety, paranoia, derealisation & Medical therapy, electroconvulsive treatment \\
\hline [90] & Greece & $C R$ & Mood disorder with manic features & Medical therapy \\
\hline [91] & Germany & $C R$ & Mania & Medical therapy \\
\hline [92] & USA & $C R$ & Borderline personality disorder with antisocial traits & Medical therapy, education about AAS, psychotherapy \\
\hline [93] & India & $C R$ & Substance dependence including opioids and AAS & $\begin{array}{l}\text { Medical therapy for AAS and opioid withdrawal, } \\
\text { psycho-education and relapse prevention }\end{array}$ \\
\hline [94] & Ireland & $C R$ & Mixed psychotic disorder & Medical therapy \\
\hline [95] & USA & $C R$ & Acute mania & Medical therapy \\
\hline [96] & UK & $C R$ & Psychosis with low mood & Medical therapy \\
\hline [97] & USA & $C R$ & AAS dependence & Drug treatment programme participation \\
\hline [98] & USA & $C R$ & AAS dependence & Medical therapy \\
\hline \multicolumn{5}{|c|}{ Neuroendocrine $(n=11)$} \\
\hline [99] & Netherlands & $C R$ & Hypogonadotropic hypogonadism & Medical therapy \\
\hline [100] & USA & $C R$ & Hypogonadism & Medical therapy \\
\hline [101] & Malaysia & $C R$ & Complete azoospermia & Medical therapy \\
\hline [102] & UK & $C R$ & Severe hypogonadotropic hypogonadism & Medical therapy \\
\hline [103] & UK & CS & Azoospermia & Advice to discontinue AAS \\
\hline [104] & USA & $C R$ & $\begin{array}{l}\text { Impotence-reduced testicular volume on both sides and } \\
\text { gynaecomastia on both sides }\end{array}$ & Medical therapy \\
\hline [105] & USA & $C R$ & Azoospermia & Discontinuation of all medications; medical therapy \\
\hline [106] & USA & RCR & Azoospermia & AAS cessation and medical therapy \\
\hline [107] & Italy & $C R$ & Hypogonadotropic hypogonadism & Medical therapy following AAS discontinuation \\
\hline [108] & USA & CS & Hypogonadism & Medical therapy \\
\hline [109] & USA & $C R$ & Azoospermia & Medical therapy \\
\hline \multicolumn{5}{|c|}{ Hepatic $(n=25)$} \\
\hline [110] & USA & $C R$ & $\begin{array}{l}\text { Tumour haemorrhage in liver. On second presentation: } \\
\text { tender hepatomegaly and haemorrhage, tachycardia }\end{array}$ & Surgery; instruction to discontinue AAS \\
\hline [111] & Mexico & $C R$ & Liver toxicity, cholestasis & Medical therapy; AAS discontinued \\
\hline [112] & USA & CS & Hepatotoxicity & Medical therapy \\
\hline [113] & USA & $C R$ & Liver toxicity & Medical therapy \\
\hline [114] & USA & CS & $\begin{array}{l}\text { Hepatotoxicity. In one case, patient suffered from renal } \\
\text { failure. }\end{array}$ & Medical therapy \\
\hline [115] & Spain & CS & $\begin{array}{l}\text { 1) Hyperechogenic lesions in the liver; 2) Acute renal } \\
\text { failure, muscular damage, metabolic alkalosis and } \\
\text { hypernatraemia }\end{array}$ & $\begin{array}{l}\text { 1) Instruction to discontinue AAS; inclusion in liver } \\
\text { transplantation program; 2) Patient received } \\
\text { haemodialysis; instruction to discontinue AAS. }\end{array}$ \\
\hline [116] & UK & $C R$ & $\begin{array}{l}\text { Hepatic rupture with cardiovascular collapse, sepsis } \\
\text { and acute renal failure }\end{array}$ & Resuscitation, surgery \\
\hline [117] & Germany & $C R$ & $\begin{array}{l}\text { Hepatocellular carcinoma. Liver was enormously } \\
\text { enlarged }\end{array}$ & $\begin{array}{l}\text { Chemoembolization was declined by patient who was } \\
\text { recommended for transplantation }\end{array}$ \\
\hline [118] & Australia & $C R$ & Hepatocellular carcinoma & Surgery \\
\hline [119] & Lebanon & $C R$ & $\begin{array}{l}\text { Liver injury resulting in prolonged cholestasis and acute } \\
\text { kidney injury }\end{array}$ & $\begin{array}{l}\text { Advice to discontinue AAS, medical therapy, plasma } \\
\text { exchange. Patient refused renal biopsy. }\end{array}$ \\
\hline [120] & China & $C R$ & Dilated cardiomyopathy and acute hepatic injury & Medical therapy \\
\hline [121] & Poland & $C R$ & Severe intrahepatic cholestasis that developed to severe & Medical therapy \\
\hline
\end{tabular}


Table 1 Summary of included studies (Continued)

\begin{tabular}{|c|c|c|c|c|}
\hline $\begin{array}{l}\text { Reference } \\
\text { no. }\end{array}$ & Country & $\begin{array}{l}\text { Study } \\
\text { design }\end{array}$ & Diagnosis & Treatment approach \\
\hline & & & liver failure & \\
\hline [122] & UK & CS & Cholestasis & Medical therapy \\
\hline [123] & Spain & $C R$ & Severe cholestatic jaundice & Unclear \\
\hline [124] & USA & CS & Severe hepatotoxicity, cholestasis & Medical therapy \\
\hline [125] & Netherlands & $C R$ & $\begin{array}{l}\text { Mild jaundice; cholestatic hepatitis identified through } \\
\text { liver biopsy }\end{array}$ & Medical therapy \\
\hline [126] & UK & $C R$ & Three grade II oesophageal varices & Blood transfusion and sclerotherapy \\
\hline [127] & Australia & $C R$ & Intrahepatic cholestasis & Medical therapy \\
\hline [128] & USA & $C R$ & $\begin{array}{l}\text { Severe cholestasis and renal failure. Re-admitted } \\
\text { with pruritus }\end{array}$ & Medical therapy \\
\hline [129] & Spain & $C R$ & Hepatic rupture, liver failure. Hematoma of the liver & Surgery \\
\hline [130] & USA & $C R$ & Acute, nonobstructive, intrahepatic cholestatic hepatitis & Medical therapy; advice to avoid other medications \\
\hline [131] & USA & $C R$ & Severe jaundice, bile acid nephropathy & Medical therapy, blood transfusion, AAS discontinued \\
\hline [132] & Spain & CS & Severe cholestasis, hepatotoxicity & Medical therapy followed by MARS therapy \\
\hline [133] & Brazil & $C R$ & Giant hepatic adenoma & Surgery \\
\hline [134] & Germany & $C R$ & Hepatocellular carcinoma & Surgery \\
\hline \multicolumn{5}{|c|}{ Kidney $(n=6)$} \\
\hline [135] & USA & $C R$ & $\begin{array}{l}\text { Initial diagnosis of hepatic adenomatosis (2004). On third } \\
\text { admission, diagnosed with chronic kidney disease and } \\
\text { coronary artery disease (2013) }\end{array}$ & $\begin{array}{l}\text { Advice given to discontinue AAS initially. Surgery } \\
\text { at later presentation. }\end{array}$ \\
\hline [136] & Spain & $C R$ & $\begin{array}{l}\text { Severe acute kidney failure with high blood pressure, } \\
\text { anaemia and thrombocytopenia }\end{array}$ & Medical therapy \\
\hline [137] & Iran & $C R$ & Acute renal failure; muscle injury and rhabdomyolysis & Medical therapy \\
\hline [138] & Brazil & CS & Acute kidney injury in both cases & Medical therapy. \\
\hline [139] & USA & $C R$ & Recurrent renal infarction & Medical therapy, AAS counselling \\
\hline [140] & Lebanon & $C R$ & Acute pancreatitis, acute renal failure and hypercalcemia. & Medical therapy \\
\hline \multicolumn{5}{|c|}{ Cardiovascular $(n=26)$} \\
\hline [141] & Japan & $C R$ & Cardioembolic stroke & Medical therapy, AAS use discontinued \\
\hline [142] & Sweden & $C R$ & $\begin{array}{l}\text { Intraparenchymal haemorrhage in right parietal lobe; } \\
\text { right cortical venous thrombosis }\end{array}$ & Anticoagulation therapy \\
\hline [143] & UK & $C R$ & Acute myocardial infarction & Surgery \\
\hline [144] & Egypt & $C R$ & Severe toxic cardiomyopathy. & Medical therapy \\
\hline [145] & Canada & $C R$ & Cardiomyopathy & $\begin{array}{l}\text { Incubation, medical therapy, resuscitation, dialysis and } \\
\text { device implantation, addiction counselling referral }\end{array}$ \\
\hline [146] & Argentina & $C R$ & Posterior territory ischemic stroke. & Intubation and ventilation; rehabilitation \\
\hline [147] & Sweden & $C R$ & Severe hypertension & $\begin{array}{l}\text { Aggressive treatment with intravenous drugs; } \\
\text { AAS cessation }\end{array}$ \\
\hline [148] & Turkey & $C R$ & Acute coronary syndrome & Medical therapy \\
\hline [149] & Sweden & CS & $\begin{array}{l}\text { i) Occlusion of all major arteries of the leg. } \\
\text { ii) Arterial thrombosis: }\end{array}$ & $\begin{array}{l}\text { i) Surgery } \\
\text { ii) Thrombolysis attempted with no improvement. } \\
\text { Surgery performed. }\end{array}$ \\
\hline$[150]$ & Canada & $C R$ & $\begin{array}{l}\text { Stroke. Upon readmission } 3 \text { years later, diffused } \\
\text { distal arterial thrombosis }\end{array}$ & Medical therapy \\
\hline [151] & Kuwait & $C R$ & Cardiomyopathy, stroke and peripheral vascular disease & Medical therapy \\
\hline [152] & Portugal & $C R$ & Severe toxic cardiomyopathy. & Medical therapy \\
\hline [153] & USA & $C R$ & Myocardial infarction & Medical therapy \\
\hline [154] & Turkey & $C R$ & Myocardial infarction & Medical therapy \\
\hline
\end{tabular}


Table 1 Summary of included studies (Continued)

\begin{tabular}{clll}
\hline $\begin{array}{l}\text { Reference } \\
\text { no. }\end{array}$ & Country & $\begin{array}{l}\text { Study } \\
\text { design }\end{array}$ & Diagnosis \\
\hline$[155]$ & Greece & CR & Myocardial infarction \\
{$[156]$} & USA & CR & Acute myocardial infarction and polycythaemia \\
{$[157]$} & Portugal & CR & Myocardial infarction \\
{$[158]$} & Turkey & CR & Acute inferior myocardial infarction, renal infarction \\
{$[159]$} & USA & CR & Acute myocardial infarction \\
{$[160]$} & USA & CR & Myocardial infarction \\
{$[161]$} & Australia & CR & Persistent atrial fibrillation \\
{$[162]$} & Germany & CR & Severe coronary heart disease \\
{$[163]$} & UK & CR & Coronary thrombus \\
{$[164]$} & USA & CR & Cardiomyopathy, severe systolic dysfunction and Class IV \\
& & & heart failure. \\
{$[165]$} & USA & CR & Cardiomyopathy, acute systolic heart failure. \\
{$[166]$} & Finland & CS & Cardiac hypertrophy
\end{tabular}

Treatment approach

Medical therapy

Surgery, medical therapy, phlebotomy.

Medical therapy.

Medical therapy, surgery

Medical therapy, rehabilitation

Medical therapy

Electrical cardioversion, medical therapy.

Surgery, medical therapy

Medical therapy

Medical therapy and device implementation until discharge.

Medical therapy, instruction not to use AAS.

Surgery, medical therapy. In one case, no treatment was reported

Musculoskeletal $(n=13)$

\begin{tabular}{|c|c|c|c|}
\hline [167] & USA & $C R$ & Tear in the midsubstance of the triceps tendon. \\
\hline [168] & Israel & $C R$ & Massive rhabdomyolysis \\
\hline [169] & Ireland & $C R$ & $\begin{array}{l}\text { Quadriceps tendon rupture, patella tendon rupture, } \\
\text { distal femur fracture, patella dislocation in both legs }\end{array}$ \\
\hline [170] & Iran & $C R$ & $\begin{array}{l}\text { Quadriceps tendon rupture in both knees and } \\
\text { partial rupture of triceps tendon. }\end{array}$ \\
\hline [171] & UK & $C R$ & Bilateral rupture of the quadriceps tendon \\
\hline [172] & Denmark & $C R$ & Complete rupture of the extensor pollicis longus tendon. \\
\hline [173] & Finland & $C R$ & Complete bilateral quadriceps tendon rupture in both legs \\
\hline [174] & UK & $C R$ & Rupture of both quadriceps tendons \\
\hline [175] & Finland & $C R$ & Bilateral distal biceps tendon avulsions \\
\hline [176] & UK & $C R$ & Complete rupture of the anterior cruciate ligament \\
\hline [177] & UK & $C R$ & $\begin{array}{l}\text { Rhabdomyolysis. Initially diagnosed with musculoskeletal } \\
\text { pain. }\end{array}$ \\
\hline [178] & UK & $C R$ & $\begin{array}{l}\text { Bilateral simultaneous traumatic upper arm compartment } \\
\text { syndromes }\end{array}$ \\
\hline & & $\mathrm{Cl}$ & Complete tear of quadriceps tendon \\
\hline
\end{tabular}

Surgery, immobilisation

Medical therapy

Surgery, immobilisation, physiotherapy

Surgery, immobilisation, physiotherapy

Surgery, immobilisation

Surgery, immobilisation

Surgery, immobilisation

Surgery, immobilisation, physiotherapy

Surgery, immobilisation, physiotherapy

Physiotherapy

Medical therapy

Surgery

Surgery, immobilisation, rehabilitation

Infectious $(n=7)$

$\begin{array}{llll}{[180]} & \text { USA } & \text { CR } & \text { Abscess. } \\ {[181]} & \text { Israel } & \text { CR } & \text { Full thickness skin and subcutaneous tissue necrosis } \\ {[182]} & \text { USA } & \text { CR } & \text { Pyomyositis } \\ {[183]} & \text { UK } & \text { CS } & \text { Injection injury } \\ {[184]} & \text { Turkey } & \text { CR } & \text { Spontaneous corpus cavernosum abscess } \\ {[185]} & \text { UK } & \text { CR } & \text { Necrotizing myositis } \\ {[186]} & \text { UK } & \text { CR } & \text { Abscess } \\ \text { ther (n= 8) } & & \\ {[187]} & \text { UK } & \text { CR } & \text { Chronic laryngitis } \\ {[188]} & \text { UK } & C R & \text { Hypokalaemia and metabolic alkalosis. } \\ {[189]} & \text { UK } & C R & \text { Abnormal lipid profile } \\ {[190]} & \text { UK } & C R & \text { Acute respiratory distress syndrome } \\ {[191]} & \text { USA } & C R & \text { Multiple organ dysfunction syndrome, acute kidney injury }\end{array}$

Medical therapy; AAS counselling

Surgery

Medical therapy, surgery

Surgery, medical therapy

Surgery

Surgery, medical therapy

Surgery, medical therapy

Medical therapy followed by laser treatments

Fluid provision

Advice to stop using AAS

Intubation and ventilation; rehabilitation.

Resuscitation, medical therapy, ventilation, 
Table 1 Summary of included studies (Continued)

\begin{tabular}{lllll}
\hline $\begin{array}{l}\text { Reference } \\
\text { no. }\end{array}$ & Country & $\begin{array}{l}\text { Study } \\
\text { design }\end{array}$ & Diagnosis & Treatment approach \\
\hline & & & and refractory supraventricular tachycardia & $\begin{array}{l}\text { haemodialysis and electrical cardioversion for different } \\
\text { symptoms. }\end{array}$ \\
{$[192]$} & USA & CR & New onset of diabetes & Medical therapy, AAS advice \\
{$[193]$} & Lebanon & CS & Spontaneous subdural haematoma & Surgery \\
{$[194]$} & UK & CR & Bilateral internal laryngocoeles & Medical therapy
\end{tabular}

$C R$ case report, $C S$ case series, $R C R$ retrospective chart review

all identified as potentially important factors to be addressed during AAS treatment $[51,52,55]$.

Two studies were identified in this review where individuals who discontinued AAS use needed treatment for subsequent psychiatric symptoms including depression and suicidal ideation [87, 89]. A further 11 studies reported treatments for neuroendocrine disorders, primarily with men who had discontinued their AAS use prior to the onset of symptoms. Administering AAS suppresses the hypothalamic-pituitary testicular axis, particularly when used in large amounts and for long periods, and inhibits production of testosterone [195]. Men who discontinue long-term AAS use are at risk of hypogonadism and while this may frequently be temporary and resolve spontaneously, it may in some cases persist for long periods after cessation, requiring medical treatment [51, 196-198]. Symptoms of hypogonadism may be behind the withdrawal experiences of people with a dependence on AAS [51]. These difficult experiences have been identified as an influencing factor in users' decisions to continue or reinstate AAS use [52]. The limited evidence here shows that positive outcomes are consistently reported in the treatment of men suffering with neuroendocrine disorders following AAS cessation.

\section{Treatment for harms associated with AAS use}

The bulk of the evidence identified related to current or former users receiving treatment for an acute or chronic condition or injury associated with their AAS use. This included psychiatric disorders $(n=12)$, hepatic and kidney disorders $(n=31)$, cardiovascular disorders $(n=26)$, musculoskeletal disorders $(n=13)$ and a range of other disorders $(n=8)$. The management of such conditions in the AAS-using group is similar to that of the general population [53] and details are described in the tables in the additional material provided. There was, however, limited evidence of engagement with users regarding their AAS use as part of their more general treatment. There were examples where participants were stated to have discontinued AAS following treatment and remained abstinent at follow-up [133, 157, 159], but patients' AAS status at this time was not routinely reported.

\section{Treatment as an opportunity for engagement}

In a small proportion of studies $(n=10)$, it was reported that some form of intervention to bring about, or maintain change in AAS use was included as part of the treatment provided. This was most commonly instruction or advice to discontinue AAS use, with a more substantial element such as counselling only reported in three studies [139, 145, 180]. Where reported, such efforts were based on suppling risk information associated with AAS but not support with discontinuation, such as managing withdrawal symptoms. No form of harm reduction interventions were initiated alongside or following any treatments provided. Only one study [145] reported signposting or referral to another service for further support.

In comparison to people who use other psychoactive drugs, AAS users are less likely to suffer acute adverse effects from their substance use, or to have their occupational performance or relationships impaired and are, therefore, less reliant upon health professionals [44]. Research has consistently indicated this group to be reluctant to seek medical help or engage with health professionals [67, 199-201]. Where health professionals identify AAS use in a patient and are providing treatment for an associated harm, this may, therefore, provide a rare opportunity to motivate changes in behaviour. There were examples in this review of studies that included recent initiators. For example, in 12/25 studies included here reporting hepatic disorders, patients had initiated AAS use fewer than 6 months prior to treatment. Contact with a health professional at this stage could provide a valuable opportunity to engage with the individual about their motivations and substance use before habitual use develops or becomes entrenched, or identify and treat any underlying factors. In a further $5 / 25$ studies, long-term AAS use of over 5 years was reported, and up to 15 years. For such individuals, this contact could provide opportunity to test for disorders associated with long-term use, promote behaviour change and discuss long-term plans for discontinuation of use.

Encouraging discontinuation and delivering harm reduction with patients treated for a disorder associated with AAS Where a patient is receiving treatment, there will be a range of factors that affect the appropriateness of delivering any 
form of AAS intervention or investigating any other potential harms. For example, in many of the studies identified, the individuals treated had discontinued their AAS use a substantial time prior to seeking treatment. Additionally, many were diagnosed with acute conditions, for which immediate, and in some cases substantial, treatment was required. In such cases, it is not surprising that the acute harm will be the focus of the treatment. However, where AAS use is suspected or confirmed, a number of diagnostic tests may be appropriate to identify potential physiological or psychiatric harms [53]. Recommendations for general practitioners who identify AAS use in a patient include strongly encouraging cessation and management of withdrawal symptoms in those that do discontinue, as well as information on injecting practices, promoting alternatives to AAS and informing about long-term health harms for those who continue to use [202]. Continued encouragement and monitoring of psychiatric and physiological complications is recommended for those who are not prepared to consider discontinuation [53].

An instruction not to use AAS may be effective in some cases, but for individuals who are highly motivated to use AAS in response to a desire to change their appearance or performance, it may have little impact. Experiencing harm or increasing knowledge of potential risks may not only reduce motivation to use amongst users who may accept risks as a potential consequence of use, but also one that they can manage through their practices [60]. Where it is identified that users intend to continue administering AAS following treatment, it is important that they receive appropriate harm reduction advice, such as on safe injecting, blood-borne viruses (BBVs) and AAS cycles. For example, in seven studies, treatments for infectious complications associating with injecting AAS were reported. There was no indication of relevant harm reduction work included alongside treatment, such as advice or demonstration relating to injecting or injecting techniques in any of these studies, with the exception of Rich and colleagues who reported provision of counselling on the risks of BBVs [180].

\section{Discussion}

Research over the past 30 years has provided a far richer understanding of the populations of AAS users, their characteristics, behaviours and motivations. While the specific risks attached to each AAS and the probability or magnitude of harm associated with highly individualised and complex drug regimens cannot be known, we now have a far greater understanding of the potential harms caused by these drugs. However, the evidence base for interventions has not kept pace. The examples of treatment identified in this review were set within primary and secondary care facilities. No studies were identified that explored the effectiveness of any approaches to encourage cessation or treat dependence within other settings where health professionals are likely to encounter users, such as steroid clinics, drugs services or NSPs. Consequently, there is a lack of any evidence on the effectiveness of such services for bringing about behaviour change in users. Within any setting there is scarce evidence on treating AAS dependence, including initiating and maintain cessation and managing withdrawal symptoms outside of case reports of former users seeking support for neuroendocrine disorders.

The findings of this scoping review are characterised by missed opportunities. While the failure to report good practice or supplementary activity is not proof that it does not occur, without confirmation we cannot make assumptions. The extensive literature outlining the symptomatic treatment of AAS-related harms within numerous medical and surgical specialisms fails to provide evidence of intervention or referral to address the major causative factor, the patients' AAS use. This scoping review has reported only a sample of the myriad of case reports involving the treatment of AAS-related harms. These case reports not only demonstrate the lack of evidence of intervention effectiveness to support the cessation of AAS use or reduce the associated harms, they also fail to show that actual activity occurred. As a minimum, future case reports should report if any assessment for AAS dependence were conducted. Details of advice or interventions provided to AAS users or any referral or signposting are also essential information. Referrals to primary care, endocrinologists, addiction specialists or harm reduction providers are essential building blocks in identifying care pathways and potential effective interventions. Case reports are published predominantly in clinical journals, often relating to medical or surgical specialisms. The publication of reports in broader health or public health journals or journals related to drug use, addiction or harm reduction would facilitate the inclusion of clinical experiences within a wider approach to addressing the harms associated with AAS use.

Despite the comprehensive research and literature relating to AAS dependence, there remains little evidence regarding effective interventions to support cessation of use or management of withdrawal. It is hoped that the development diagnostic tools [46], guidelines for clinical management [85] and harm reduction [82] or the commissioning of health services [83] will be accompanied by robust research and evaluation. Evaluations to date have been small scale and lack generalizability.

In addition to the need to ensure accurate and consistent reporting of activity and an upscaling of research and evaluation, there is a need to ensure that interventions are culturally appropriate to the target groups. Much of the work to date has focused on the bodybuilding communities of North America, Northern Europe and Australia. It is clear that AAS use is a global issue, 
with research emerging from low-middle income countries around the world in addition to industrialised highincome states. Of added significance is the diversity of individual AAS users. Interventions will need to be tailored to meet the varied characteristics and motivations of users, going beyond those looking to achieve a stylised "bodybuilding appearance" or excel at sport or even the young males attempting to bulk up. Evidence from the United Kingdom indicates that there are as many AAS users over 40 years of age as there are those under the age of 25 years [31]. It is well established that AAS use is not restricted to men and while rates amongst women are much lower [203], the complexities of treatment and care are undoubtedly much higher $[23,204,205]$. Prevalence of AAS use is higher amongst groups with specific characteristics such as professions where size or strength is an asset [206-209], amongst gay and bisexual men $[20,22,29,210,211]$ and those using or who have previously used other drugs [212] [30, 33, 67, 212-214]. These "sub groups" may or may not require specific interventions and may merely illustrate the complexities of human nature. The majority of AAS users will not initiate or continue AAS by virtue of membership of one of these groups but will have a range of susceptibilities and motivations for use.

Beyond these challenges, to develop effective services for users of AAS is the ongoing lack of confidence that some communities of AAS users feel towards health care professionals and primary care in particular [30, 67, 199] and a feeling that reliable and relevant health information can be gained elsewhere [215]. Built on the long-standing dismissive approach towards the effectiveness of anabolic steroids by elements of the health profession [216, 217] and an ongoing 'just say no' stance amongst some practitioners, it is evident that establishing trust through listening to the AAS-using communities will be an essential element of intervention and service development [26].

\section{Conclusions}

This scoping review of the literature has identified treatments given to AAS users for a wide range of physiological and psychological harms. Despite the large number of articles identified, the evidence base consists of case reports of predominantly treatment of physiological harms and there is scarce evidence on treating dependence, managing withdrawal, or initiating behaviour change in users in any settings. Evidence is urgently required to support the development of effective services for users and of evidence-based guidance and interventions to respond to users in a range of healthcare settings. More consistent reporting in articles of whether engagement or assessment relating to AAS was initiated, and publication within broader health- or drug-related journals, will support development of the evidence base.

\section{Supplementary information}

Supplementary information accompanies this paper at https://doi.org/10. 1186/s12954-019-0343-1.

Additional file 1. Data extraction tables. The data extraction tables contain the full data extracted from the 109 articles included in the review. This includes participant information, condition requiring treatment, the treatment provided and the outcomes of treatment.

Additional file 2. Search strategy. The full search strategy used in Medline is provided.

\section{Abbreviations}

AAS: Anabolic androgenic steroids; BBV : Blood-borne virus; DSM: Diagnostic and statistical manual of mental disorders; NSP: Needle and syringe programme

\section{Acknowledgements}

Not applicable.

\section{Authors' contributions}

GB managed the review and lead protocol development, evidence search, article screening, data extraction and data synthesis. GB drafted the article methodology and result sections. MCVH provided methodological and topic expertise and helped to shape the review through supporting the development of the protocol and search strategy. MCVH screened a proportion of articles and commented on findings and written drafts. JT provided medical expertise supporting the development of the review and presentation of data, checked data extraction, and commented on written drafts. JMV provided topic expertise and helped to shape the review through supporting the development of the protocol, data extraction, data synthesis and presentation of findings. JMV drafted the article introduction and discussion sections. All authors read and approved the final manuscript.

\section{Funding}

No funding was received to support this review.

\section{Availability of data and materials}

All data generated or analysed during this study are included in this published article and its supplementary information files.

Ethics approval and consent to participate Not applicable.

\section{Consent for publication}

Not applicable.

\section{Competing interests}

The authors declare that they have no competing interests.

\section{Author details}

${ }^{1}$ Public Health Institute, Liverpool John Moores University, Liverpool, England. ${ }^{2} \mathrm{MRC} / \mathrm{CSO}$ SPHSU, University of Glasgow, Glasgow, Scotland. ${ }^{3}$ Department of Sociology, Manchester Metropolitan University, Manchester, England.

Received: 2 May 2019 Accepted: 21 November 2019

Published online: 30 December 2019

\section{References}

1. Evans-Brown M, McVeigh J, Perkins C, Bellis M. Human enhancement drugs: the emerging challenges to public health. Liverpool: North West Public Health Observatory; 2012.

2. McVeigh J, Evans-Brown M, Bellis MA. Human enhancement drugs and the pursuit of perfection. Adicciones. 2012;24(3):185-90.

3. Kanayama G, Pope HG. History and epidemiology of anabolic androgens in athletes and non-athletes. Mol Cell Endocrinol. 2018;464(C):4-13.

4. Kanayama G, Kaufman MJ, Pope HG. Public health impact of androgens. Curr Opin Endocrinol. 2018;25(3):218-23.

5. McVeigh J, Begley E. Anabolic steroids in the UK: an increasing issue for public health. Drugs. 2017;24(3):278-85. 
6. Sagoe D, Pallesen S. Androgen abuse epidemiology. Curr Opin Endocrinol Diabetes Obes. 2018;25(3):185-94.

7. Anderson LJ, Tamayose JM, Garcia JM. Use of growth hormone, IGF-I, and insulin for anabolic purpose: Pharmacological basis, methods of detection, and adverse effects. Mol Cell Endocrinol. 2017.

8. Van Hout MC, Hearne E. Netnography of female use of the synthetic growth hormone CJC-1295: pulses and potions. Subst Use Misuse. 2016; 51(1):73-84.

9. Brennan $\mathrm{R}$, Van Hout MC, Wells J. Heuristics of human enhancement risk: a little chemical help? Int J Health Prom Educ. 2013;51(4):212-27.

10. Thevis M, Thomas A, Kohler M, Beuck S, Schanzer W. Emerging drugs: mechanism of action, mass spectrometry and doping control analysis. J Mass Spectrom. 2009:44(4):442-60.

11. Thevis M, Beuck S, Thomas A, Kortner B, Kohler M, Rodchenkov G, et al. Doping control analysis of emerging drugs in human plasma - identification of GW501516, S-107, JTV-519, and S-40503. Rapid Commun Mass Spectrom. 2009:23(8):1139-46.

12. Holt RI, Sonksen PH. Growth hormone, IGF-I and insulin and their abuse in sport. Br J Pharmacol. 2008;154(3):542-56.

13. Evans-Brown M, McVeigh J. Injecting human growth hormone as a performance-enhancing drug-perspectives from the United Kingdom. J Substance Use. 2009;14(5):267-88.

14. Underwood M. "Slin is the safest and most anabolic hormone": exploring bodybuilders' use of insulin as a performance and image enhancing drug. Drug Alcohol Rev. 2018;37:S70-S.

15. Ulrich R, Pope HG, Cleret L, Petroczi A, Nepusz T, Schaffer J, et al. Doping in two elite athletics competitions assessed by randomized-response surveys. Sports Med. 2018;48(1):211-9.

16. Mottram DR, Chester N. Drugs in Sport. 7 ed: Routledge; 2018.

17. Backhouse SH, Griffiths C, McKenna J. Tackling doping in sport: a call to take action on the dopogenic environment. Br J Sports Med. 2017.

18. Auchus RJ, Brower KJ. The public health consequences of performanceenhancing substances: who bears responsibility? JAMA. 2017;318(20):1983-4.

19. Sagoe D, Molde H, Andreassen CS, Torsheim T, Pallesen S. The global epidemiology of anabolic-androgenic steroid use: a meta-analysis and meta-regression analysis. Ann Epidemiol. 2014:24(5):383-98.

20. Ip EJ, Doroudgar S, Shah-Manek B, Barnett MJ, Tenerowicz MJ, Ortanez M, et al. The CASTRO study: unsafe sexual behaviors and illicit drug use among gay and bisexual men who use anabolic steroids. Am J Addict. 2019;28:101.

21. Blashill AJ, Calzo JP, Griffiths S, Murray SB. Anabolic steroid misuse among US adolescent boys: disparities by sexual orientation and race/ethnicity. Am J Public Health 2017(0):e1-e3.

22. Griffiths S, Murray SB, Dunn M, Blashill AJ. Anabolic steroid use among gay and bisexual men living in Australia and New Zealand: Associations with demographics, body dissatisfaction, eating disorder psychopathology, and quality of life. Drug Alcohol Dependence. 2017;181:170-6.

23. Börjesson A, Gårevik N, Dahl M-L, Rane A, Ekström L. Recruitment to doping and help-seeking behavior of eight female AAS users. Subst Abuse Treat Prev Policy. 11(2016, 1):11.

24. Zahnow R, McVeigh J, Bates G, Hope V, Kean J, Campbell J, et al. Identifying a typology of men who use anabolic androgenic steroids (AAS). Int J Drug Policy. 2018;55:105-12.

25. Christiansen AV, Vinther AS, Liokaftos D. Outline of a typology of men's use of anabolic androgenic steroids in fitness and strength training environments. Drugs. 2016:24(3):295-305.

26. Underwood $\mathrm{M}$. The unintended consequences of the current approach to blood borne virus prevention amongst people who inject image and performance enhancing drugs: a commentary based on enhanced bodybuilder perspectives. Int J Drug Policy. 2019;67:19-23.

27. Ip EJ, Trinh K, Tenerowicz MJ, Pal J, Lindfelt TA, Perry PJ. Characteristics and behaviors of older male anabolic steroid users. J Pharm Pract. 2015;28(5):450-6.

28. Teck JTW, McCann M. Tracking internet interest in anabolic-androgenic steroids using Google Trends. Int J Drug Policy. 2018;51:52-5.

29. Ip EJ, Yadao MA, Shah BM, Doroudgar S, Perry PJ, Tenerowicz MJ, et al. Polypharmacy, infectious diseases, sexual behavior, and psychophysical health among anabolic steroid-using homosexual and heterosexual gym patrons in San Francisco's Castro District. Subst Use Misuse. 2017;52(7): 959-68.

30. Hope VD, McVeigh J, Marongiu A, Evans-Brown M, Smith J, Kimergard A, et al. Prevalence of, and risk factors for, HIV, hepatitis $B$ and $C$ infections among men who inject image and performance enhancing drugs: a crosssectional study. BMJ Open. 2013;3(9):e003207-e.

31. Begley E, McVeigh J, Hope V, Bates G, Glass R, Campbell J, et al. Image and Performance Enhancing Drugs: 2016 National Survey Results. Liverpool: Liverpool John Moores University; 2017.

32. Dodge T, Hoagland MF. The use of anabolic androgenic steroids and polypharmacy: A review of the literature. Drug Alcohol Depend. 2011.

33. Sagoe D, McVeigh J, Bjornebekk A, Essilfie MS, Andreassen CS, Pallesen S. Polypharmacy among anabolic-androgenic steroid users: a descriptive metasynthesis. Subst Abuse Treat Pr. 2015;10(ARTN 12).

34. Jennings CJ, Patten E, Kennedy MC, Kelly C. Examining the profile and perspectives of individuals attending harm reduction services who are users of performance and image enhancing drugs. Merchants Quay Ireland: Dublin; 2014.

35. Llewellyn W. Anabolics. 11 ed. Jupiter, FL: Molecular Nutrition; 2017.

36. Pope HG, Wood RI, Rogol A, Nyberg F, Bowers L, Bhasin S. Adverse health consequences of performance-enhancing drugs: an Endocrine Society scientific statement. Endocr Rev. 2014;35(3):341-75.

37. Westlye LT, Kaufmann T, Alnaes D, Hullstein IR, Bjornebekk A. Brain connectivity aberrations in anabolic-androgenic steroid users. Neuroimage Clin. 2017:13:62-9.

38. Bjornebekk A, Walhovd KB, Jorstad ML, Due-Tonnessen P, Hullstein IR, Fjell AM. Structural brain imaging of long-term anabolic-androgenic steroid users and nonusing weightlifters. Biol Psychiatry. 2017;82(4):294-302.

39. Hope VD, McVeigh J, Smith J, Glass R, Njoroge J, Tanner C, et al. Low levels of hepatitis $C$ diagnosis and testing uptake among people who inject image and performance enhancing drugs in England and Wales, 2012-15. Drug Alcohol Depend. 2017;179:83-6.

40. Hope VD, Harris R, McVeigh J, Cullen KJ, Smith J, Parry JV, et al. Risk of HIV and hepatitis B and C over time among men who inject image and performance enhancing drugs in England and Wales: Results from cross-sectional prevalence surveys, 1992-2013. Jaids-J Acq Imm Def. 2016;71(3):331-7.

41. Ip EJ, Yadao MA, Shah BM, Lau B. Infectious disease, injection practices, and risky sexual behavior among anabolic steroid users. Aids Care. 2016:28(3):294-9.

42. Rowe R, Berger I, Yaseen B, Copeland J. Risk and blood-borne virus testing among men who inject image and performance enhancing drugs, Sydney, Australia. Drug Alcohol Rev. 2017;36(5):658-66.

43. Iversen J, Hope VD, McVeigh J. Access to needle and syringe programs by people who inject image and performance enhancing drugs. Int J Drug Policy. 2016;31:199-200.

44. Kanayama G, Brower K, Wood R, Hudson J, Pope H. Anabolic-androgenic steroid dependence: an emerging disorder. Addiction. 2009;104(12):1966-78.

45. Association AP. Diagnostic and statistical manual of mental disorders (DSM$\left.5^{\oplus}\right)$ : American Psychiatric Pub; 2013.

46. Kanayama G, Brower KJ, Wood RI, Hudson Jl, Pope HG. Issues for DSM-V: clarifying the diagnostic criteria for anabolic-androgenic steroid dependence. Am J Psychiatr. 2009;166(6):642-4.

47. Kashkin KB, Kleber HD. Hooked on hormones?: An anabolic steroid addiction hypothesis. JAMA. 1989:262(22):3166-70.

48. Brower KJ. Rehabilitation for anabolic-androgenic steroid dependence. Clin Sport Med. 1989:1:171-81.

49. Giannini AJ, Miller N, Kocjan DK. Treating steroid abuse: a psychiatric perspective. Clin Pediatr. 1991;30(9):538-42.

50. Corcoran JP, Longo ED. Psychological treatment of anabolic-androgenic steroid-dependent individuals. J Subst Abuse Treat. 1992;9(3):229-35.

51. Brower KJ. Anabolic steroid abuse and dependence in clinical practice. Phys Sportsmed. 2009;37(4):131-40.

52. Kanayama G, Brower KJ, Wood Rl, Hudson Jl, Pope HG Jr. Treatment of anabolic-androgenic steroid dependence: Emerging evidence and its implications. Drug Alcohol Depend. 2010;109(1-3):6-13.

53. Casavant M, Griffith J. Anabolic steroid use disorder New Jersey: BMJ Americas Office; 2017 [Available from: https://bestpractice.bmj.com/topics/ en-gb/987]. Accessed Aug 2018.

54. Malone DA, Dimeff RJ, Lombardo JA, Sample RH. Psychiatric effects and psychoactive substance use in anabolic-androgenic steroid users. Clin J Sport Med. 1995;5(1):25-31.

55. Arver S, Borjesson A, Bottiger Y, Edin A, Garevic N, Lundmark J, et al. Swedish clinical guidelines on: The abuse of anabolic androgenic steroids and other hormonal drugs. Stockholm: Karolinska University Hospital; 2013. 
56. Rohman L. The relationship between anabolic androgenic steroids and muscle dysmorhpia: a review. Eating Disord. 2009;17(3):187-99.

57. Kanayama G, Barry S, Hudson J, Pope H. Body image and attitudes toward male roles in anabolic-androgenic steroid users. Am J Psychiatr. 2006;163(4): 697-703.

58. Pope H, Gruber AJ, Choi P, Olivardia R, Phillips KA. Muscle dysmorphia: an underrecognized form of body dysmorphic disorder. Psychosomatics. 1997; 38(6):548-57.

59. McVeigh J. The public health implications of anabolic steroid use in the United Kingdom. A shot in the Dark: Steroids, IPEDs - the Hidden Harm Conference; 26th April 2018; Colchester2018.

60. Hanley Santos G, Coomber R. The risk environment of anabolic-androgenic steroid users in the UK: examining motivations, practices and accounts of use. Int J Drug Policy. 2017:40:35-43.

61. Bates G, Tod D, Leavey C, McVeigh J. An evidence-based socioecological framework to understand men's use of anabolic androgenic steroids and inform interventions in this area. Drugs. 2018:1-9.

62. Pope HG, Kanayama G, Hudson Jl. Risk factors for illicit anabolic-androgenic steroid use in male weightlifters: a cross-sectional cohort study. Biol Psychiatr. 2012;71(3):254-61.

63. de Ronde W. Preventing anabolic steroid abuse: a long way to go. J Intern Med. 2018.

64. Bates G, Begley E, Tod D, Jones L, Leavey C, McVeigh J. A systematic review investigating the behaviour change strategies in interventions to prevent misuse of anabolic steroids. J Health Psychol. 2017. https://doi.org/10.1177/ 1359105317737607.

65. Backhouse S, Collins C, Defoort Y, McNamee M, Parkinson A, Sauer M. Study on doping prevention: a map of legal, regulatory and prevention practice provisions in EU 28. Luxembourg: Publications Office of the European Union; 2014. Report No.: 9279435426.

66. NICE. Drug misuse prevention: targeted interventions (NG64). London: NICE; 2017.

67. Zahnow R, McVeigh J, Ferris J, Winstock A. Adverse effects, health service engagement, and service satisfaction among anabolic androgenic steroid users. Contemp Drug Prob. 2017:44(1):69-83.

68. Kimergard A, McVeigh J. Variability and dilemmas in harm reduction for anabolic steroid users in the UK: a multi-area interview study. Harm Reduct J. 2014;11(ARTN 19).

69. Dunn M, Henshaw R, McKay F. Understanding health service use and needs of performance and image enhancing drug users in regional Queensland. Drug Alcohol Rev. 2014;33:24.

70. Wade $\mathrm{CH}$. Anabolic steroids: doctors denounce them, but athletes aren't listening. Science. 1972;176:1401-3.

71. Brower KJ, Blow FC, Beresford TP, Fuelling C. Anabolic-androgenic steroid dependence. J Clin Psychiatry. 1989;50(1):31-3.

72. Copeland J, Peters R, Dillon P. A study of 100 anabolic-androgenic steroid users. Med J Aust. 1998;168(6):311-2.

73. Midgley SJ, Heather N, Davies JB. Dependence-producing potential of anabolic-androgenic steroids. Addict Res. 1999;7(6):539-50.

74. Pope HG Jr, Kanayama G, Athey A, Ryan E, Hudson Jl, Baggish A. The lifetime prevalence of anabolic-androgenic steroid use and dependence in Americans: current best estimates. Am J Addict. 2014;23(4):371-7.

75. Ip EJ, Lu DH, Barnett MJ, Tenerowicz MJ, Vo JC, Perry PJ. Psychological and physical impact of anabolic-androgenic steroid dependence. Pharmacotherapy. 2012;32(10):910-9.

76. Pope HG Jr, Kean J, Nash A, Kanayama G, Samuel DB, Bickel WK, et al. A diagnostic interview module for anabolic-androgenic steroid dependence: preliminary evidence of reliability and validity. Exp Clin Psychopharmacol. 2010;18(3):203-2013.

77. Van de Ven K, Maher L, Wand H, Memedovic S, Jackson E, Iversen J. Health risk and health seeking behaviours among people who inject performance and image enhancing drugs who access needle syringe programs in Australia. Drug Alcohol Rev. 2018:doi: https://doi.org/10.1111/dar.12831.

78. Jacka B, Peacock A, Degenhardt L, Bruno R, Clare P, Kemp R, et al. Trends in PIEDs use among male clients of needle-syringe programs in Queensland, Australia; 2007-2015. Int J Drug Policy. 2017;46:74-8.

79. Kimergard A, McVeigh J. Environments, risk and health harms: a qualitative investigation into the illicit use of anabolic steroids among people using harm reduction services in the UK. BMJ OPEN. 2014;4(6).

80. McVeigh J, Beynon C, Bellis MA. New challenges for agency based syringe exchange schemes: analysis of 11 years of data (1991-2001) in
Merseyside and Cheshire, United Kingdom. Int J Drug Policy. 2003;14(5-6):399-405.

81. Glass R, Hope VD, Njoroge J, Edmundson C, Smith J, McVeigh J, et al. Secondary distribution of injecting equipment obtained from needle and syringe programmes by people injecting image and performance enhancing drugs: England and Wales, 2012-15. Drug Alcohol Depend. 2018;195:40-4.

82. NICE. Needle and syringe programmes NICE public health guidance. NICE: National Institute for Health and Care Excellence; 2014.

83. Public Health England. Providing effective services for people who use image and performance enhancing drugs. London: PHE Publications; 2015.

84. HM Government. 2017 Drug Strategy. London 2017.

85. Department of Health. Drug misuse and dependence: UK guidelines on clinical management. London: Department of Health; 2017.

86. Arksey H, O'Malley L. Scoping studies: towards a methodological framework. Int J Soc Res Methodol. 2005;8(1):19-32.

87. Malone DA, Dimeff RJ. The use of fluoxetine in depression associated with anabolic steroid withdrawal: a case series. J Clin Psychiatry. 1992;53(4):130-2.

88. Hays LR, Littleton S, Stillner V. Anabolic steroid dependence. Am J Psychiatr. 1990;147(1):122.

89. Allnutt S, Chaimowitz G. Anabolic steroid withdrawal depression: a case report. The Canadian Journal of Psychiatry / La Revue canadienne de psychiatrie. 1994;39(5):317-8.

90. Papazisis G, Kouvelas D, Mastrogianni A, Karastergiou A. Anabolic androgenic steroid abuse and mood disorder: a case report. Int J Neuropsychopharmacol. 2007;10(2):291-3.

91. Gahr M, Kolle MA, Baumgarten E, Freudenmann RW. Mania related to mesterolone in a previously mentally healthy person. J Clinical Psychopharmacol. 2012;32(5):734-5.

92. Rashid W. Testosterone abuse and affective disorders. J Subst Abuse Treatment. 2000;18(2):179-84.

93. Ranjan R, Parmar A, Pattanayak RD, Dhawan A. Dependence on anabolic-androgenic steroids: a case report and brief review. Delhi Psychiatry J. 2014;17(2):481-4.

94. Duffy RM, Kelly BD. Steroids, psychosis and poly-substance abuse. Irish J Psychol Med. 2015:32(2):227-30.

95. Franey DG, Espiridion ED. Anabolic steroid-induced mania. Cureus. 2018; 10(8):e3163-e.

96. Stanley A, Ward M. Anabolic steroids--the drugs that give and take away manhood. A case with an unusual physical sign. Med Sci Law. 1994;34(1):82-3.

97. Brower KJ, Blow FC, Beresford TP, Fuelling C. Anabolic-androgenic steroid dependence. J Clin Psychiatry. 1989;50:31.

98. Tennant F, Black DL, Voy RO. Anabolic steroid dependence with opioid-type features. N Engl J Med. 1988:319(9):578.

99. van Breda E, Keizer HA, Kuipers H, Wolffenbuttel BHR. Androgenic anabolic steroid use and severe hypothalamic-pituitary dysfunction: a case study. Int J Sports Med. 2003;24(3):195-6.

100. Tan RS, Vasudevan D. Use of clomiphene citrate to reverse premature andropause secondary to steroid abuse. Fertility Sterility. 2003;79(1):203-5.

101. Menon DK. Successful treatment of anabolic steroid-induced azoospermia with human chorionic gonadotropin and human menopausal gonadotropin. Fertil Steril. 2003;79(Suppl 3):1659-61.

102. Gill GV. Anabolic steroid induced hypogonadism treated with human chorionic gonadotropin. Postgrad Med J. 1998;74(867):45-6.

103. Gazvani MR, Buckett W, Luckas MJ, Aird IA, Hipkin LJ, Lewis-Jones DI. Conservative management of azoospermia following steroid abuse. Hum Reprod. 1997;12(8):1706-8.

104. Bickelman C, Ferries L, Eaton RP. Impotence related to anabolic steroid use in a body builder. Response to clomiphene citrate. Western J Med. 1995; 162(2):158-60.

105. Turek PJ, Williams RH, Gilbaugh JH III, Lipshultz LI. The reversibility of anabolic steroid-induced azoospermia. J Urol. 1995;153(5):1628-30.

106. Cohen JJ, Honig S. Anabolic steroid-associated infertility: a potentially treatable and reversible cause of male infertility. Fertility Sterility. 2005;84: S223

107. Pirola I, Cappelli C, Delbarba A, Scalvini T, Agosti B, Assanelli D, et al. Anabolic steroids purchased on the Internet as a cause of prolonged hypogonadotropic hypogonadism. Fertility Sterility. 2010;94(6):2331.e1-3.

108. Street C, Scally MC. Pharmaceutical intervention of anabolic steroid induced hypogonadism - our success at restoration of the HPG axis. Med Sci Sports Exercise. 2000;32(5S) 
109. Jarow JP, Lipshultz LI. Anabolic steroid-induced hypogonadotropic hypogonadism. Am J Sports Med. 1990;18(4):429-31.

110. Martin NM, Abu Dayyeh BK, Chung RT. Anabolic steroid abuse causing recurrent hepatic adenomas and hemorrhage. World J Gastroenterol. 2008; 14(28):4573-5.

111. Sánchez-Osorio M, Duarte-Rojo A, Martínez-Benítez B, Torre A, Uribe M. Anabolic-androgenic steroids and liver injury. Liver Int. 2008;28(2):278-82.

112. Chahla E, Hammami MB, Befeler AS. Hepatotoxicity associated with anabolic androgenic steroids present in over-the-counter supplements: a case series. International Journal of Applied. 2014;4(3).

113. Awai HI, Yu EL, Ellis LS, Schwimmer JB. Liver toxicity of anabolic androgenic steroid use in an adolescent with nonalcoholic fatty liver disease. J Pediatr Gastroenterol Nutr. 2014;59(3):e32-e3.

114. Krishnan PV, Feng Z-Z, Gordon SC. Prolonged intrahepatic cholestasis and renal failure secondary to anabolic androgenic steroid-enriched dietary supplements. J Clin Gastroenterol. 2009;43(7):672-5.

115. Socas L, Zumbado M, Perez-Luzardo O, Ramos A, Perez C, Hernandez JR, et al. Hepatocellular adenomas associated with anabolic androgenic steroid abuse in bodybuilders: a report of two cases and a review of the literature. Br J Sports Med. 2005;39(5):e27.

116. Patil JJ, O'Donohoe B, Loyden CF, Shanahan D. Near-fatal spontaneous hepatic rupture associated with anabolic androgenic steroid use: a case report. Br J Sports Med. 2007:41(7):462-3.

117. Solbach P, Potthoff A, Raatschen HJ, Soudah B, Lehmann U, Schneider A, et al. Testosterone-receptor positive hepatocellular carcinoma in a 29-year old bodybuilder with a history of anabolic androgenic steroid abuse: a case report. BMC Gastroenterol. 2015;15:60

118. Gorayski P, Thompson CH, Subhash HS, Thomas AC. Hepatocellular carcinoma associated with recreational anabolic steroid use. Br J Sports Med. 2008:42(1):74-5 discussion 5.

119. El Khoury C, Sabbouh T, Farhat H, Ferzli A. Severe cholestasis and bile cast nephropathy induced by anabolic steroids successfully treated with plasma exchange. Case Reports Med. 2017;2017

120. Li C, Adhikari BK, Gao L, Zhang S, Liu Q, Wang Y, et al. Performanceenhancing drugs abuse caused cardiomyopathy and acute hepatic injury in a young bodybuilder. Am J Mens Health. 2018;12(5):1700-4

121. Stepien PM, Reczko K, Wieczorek A, Zarebska-Michaluk D, Pabjan P, Krol $T$, et al. Severe intrahepatic cholestasis and liver failure after stanozolol usage - case report and review of the literature. Clin Exper Hepatol. 2015:1(1):30-3.

122. Elsharkawy AM, McPherson S, Masson S, Burt AD, Dawson RT, Hudson M. Cholestasis secondary to anabolic steroid use in young men. BMJ. 2012;344:e468.

123. Ampuero J, Garcia ES, Lorenzo MM, Calle R, Ferrero P, Gomez MR. Stanozolol-induced bland cholestasis. Gastroenterol Hepatol. 2014;37(2):71-2

124. Singh V, Rudraraju M, Carey EJ, Byrne TJ, Vargas HE, Williams JE, et al. Severe hepatotoxicity caused by a methasteron-containing performance-enhancing supplement. J Clin Gastroenterol. 2008;43(3):287.

125. Boks M, Tiebosch AT, van der Waaij LA. A jaundiced bodybuilder Cholestatic hepatitis as side effect of injectable anabolic-androgenic steroids AU - Boks. Marije N J Sport Sci. 2017;35(22):2262-4.

126. Winwood PJ, Robertson DA, Wright R. Bleeding oesophageal varices associated with anabolic steroid use in an athlete. Postgrad Med J. 1990; 66(780):864-5.

127. Ding NS, De Cruz P, Lim L, Thompson A, Desmond P. Androgenic-anabolic steroid drug-induced liver injury. Intern Med J. 2013;43(2):215-6.

128. Nasr J, Ahmad J. Severe cholestasis and renal failure associated with the use of the designer steroid Superdrol (methasteron): a case report and literature review. Dig Dis Sci. 2009;54(5):1144-6.

129. Marcacuzco Quinto AA, Manrique Municio A, Loinaz Segurola C, Jimenez Romero LC. Spontaneous hepatic rupture associated with the use of anabolic steroids. Cirugia Espanola. 2014;92(8):570-2.

130. Hymel BM, Victor DW, Alvarez L, Shores NJ, Balart LA. Mastabol induced acute cholestasis: a case report. World J Hepatol. 2013;5(3):133-6.

131. Flores A, Nustas R, Nguyen HL, Rahimi RS. Severe cholestasis and bile acid nephropathy from anabolic steroids successfully treated with plasmapheresis. ACG Case Rep J. 2016:3(2):133-5.

132. Diaz FC, Saez-Gonzalez E, Benlloch S, Alvarez-Sotomayor D, Conde I, Polo B, et al. Albumin dialysis with MARS for the treatment of anabolic steroidinduced cholestasis. Ann Hepatol. 2016;15(6):939-43.
133. Pais-Costa SR, Lima OA, Soares AF. Giant hepatic adenoma associated with anabolic-androgenic steroid abuse: case report. Arquivos brasileiros de cirurgia digestiva : $A B C D=$ Brazilian archives of digestive surgery. 2012;25(3): 180-2.

134. Hardt A, Stippel D, Odenthal M, Hölscher AH, Dienes H-P, Drebber U. Development of hepatocellular carcinoma associated with anabolic androgenic steroid abuse in a young bodybuilder: a case report. Case Reports in Pathology. 2012;2012:195607.

135. Kesler T, Sandhu RS, Krishnamoorthy S. Hepatology: hepatocellular carcinoma in a young man secondary to androgenic anabolic steroid abuse. J Gastroenterol Hepatol. 2014;29(11):1852.

136. Merino Garcia E, Borrego Utiel FJ, Martinez Arcos MA, Borrego Hinojosa J, Perez Del Barrio MP. Kidney damage due to the use of anabolic androgenic steroides and practice of bodybuilding. Nefrologia. 2018;38(1):101-3.

137. Tarashande Foumani A, Elyasi F. Oxymetholone-induced acute renal failure: a case report. Caspian J Intern Med. 2018;9(4):410-2

138. Daher EF, Silva Junior GB, Queiroz AL, Ramos LM, Santos SQ, Barreto DM, et al. Acute kidney injury due to anabolic steroid and vitamin supplement abuse: report of two cases and a literature review. Int Urol Nephrol. 2009;41(3):717-23.

139. Colburn S, Childers WK, Chacon A, Swailes A, Ahmed FM, Sahi R. The cost of seeking an edge: recurrent renal infarction in setting of recreational use of anabolic steroids. Anna Med Surgery (2012). 2017;14:25-8.

140. Samaha AA, Nasser-Eddine W, Shatila E, Haddad JJ, Wazne J, Eid AH. Multiorgan damage induced by anabolic steroid supplements: a case report and literature review. J Med Case Rep. 2008;2:340.

141. Shimada Y, Yoritaka A, Tanaka Y, Miyamoto N, Ueno Y, Hattori N, et al. Cerebral infarction in a young man using high-dose anabolic steroids. J Stroke Cerebrovasc Dis. 2012;21(8):906.e9-11.

142. Sveinsson O, Herrman L. Cortical venous thrombosis following exogenous androgen use for bodybuilding. BMJ Case Rep. 2013;2013.

143. Garg P, Davis G, Wilson Jl, Sivananthan M. Intravascular ultrasound and angiographic demonstration of left main stem thrombus-high-risk presentation in a young adult with anabolic steroid abuse. Am Heart Hosp J. 2010;8(2):E125-E7.

144. Shamloul RM, Aborayah AF, Hashad A, Abd-Allah F. Anabolic steroids abuseinduced cardiomyopathy and ischaemic stroke in a young male patient. BMJ Case Rep. 2014;2014.

145. Luc JGY, Buchholz H, Kim DH, MacArthur RGG. Left ventricular assist device for ventricular recovery of anabolic steroid-induced cardiomyopathy. J Surg Case Rep. 2018;2018(8):rjy221-rjy.

146. Santamarina RD, Besocke AG, Romano LM, Ioli PL, Gonorazky SE. Ischemic stroke related to anabolic abuse. Clin Neuropharmacol. 2008;31(2):80-5.

147. Edvardsson B. Hypertensive encephalopathy associated with anabolicandrogenic steroids used for bodybuilding. Acta Neurologica Belgica. 2015; 115(3):457-8.

148. Sonmez E, Turkdogan KA, Yilmaz C, Kucukbuzcu S, Ozkan A, Sogutt O. Chronic anabolic androgenic steroid usage associated with acute coronary syndrome in bodybuilder. Turkish J Emerg Med. 2016;16(1):35-7.

149. Falkenberg $M$, Karlsson J, Ortenwall P. Peripheral arterial thrombosis in two young men using anabolic steroids. Eur J Vasc Endovasc. 1997;13(2):223-6.

150. Laroche GP. Steroid anabolic drugs and arterial complications in an athlete-a case history. Angiology. 1990;41(11):964-9.

151. Youssef MYZ, Alqallaf A, Abdella N. Anabolic androgenic steroid-induced cardiomyopathy, stroke and peripheral vascular disease. BMJ Case Reports. 2011:2011. https://doi.org/10.1136/bcr.12.2010.3650.

152. Bispo M, Valente A, Maldonado R, Palma R, Glória H, Nóbrega J, et al. Anabolic steroid-induced cardiomyopathy underlying acute liver failure in a young bodybuilder. World J Gastroenterol. 2009;15(23):2920.

153. Goldstein DR, Dobbs T, Krull B, Plumb VJ. Clenbuterol and anabolic steroids: a previously unreported cause of myocardial infarction with normal coronary arteriograms. South Med J. 1998;91(8):780-4.

154. Günep Y, Erbap C, Okuyan E, Babalýk E, Gürmen T. Myocardial infarction with intracoronary thrombus induced by anabolic steroids. Anatol J Cardiol. 2004:4(4):357-8

155. Christou GA, Christou KA, Nikas DN, Goudevenos JA. Acute myocardial infarction in a young bodybuilder taking anabolic androgenic steroids: a case report and critical review of the literature. Eur J Prev Cardiol. 2016; 23(16):1785-96.

156. Stergiopoulos K, Brennan JJ, Mathews R, Setaro JF, Kort S. Anabolic steroids, acute myocardial infarction and polycythemia: a case report and review of the literature. Vasc Health Risk Manag. 2008;4(6):1475-80. 
157. Santos RP, Pereira A, Guedes H, Lourenço C, Azevedo J, Pinto P. Anabolic drugs and myocardial infarction - a clinical case report. Arquivos brasileiros de cardiologia. 2015;105(3):316-9.

158. Ýlhan E, Demirci D, Güvenç TS, Çalýk AN. Acute myocardial infarction and renal infarction in a bodybuilder using anabolic steroids. Turk Kardiyol Dern Ars. 2010;38(4):275-8.

159. Huie MJ. An acute myocardial infarction occurring in an anabolic steroid user. Med Sci Sports Exerc. 1994;26(4):408-13.

160. Ferenchick GS, Adelman S. Myocardial infarction associated with anabolic steroid use in a previously healthy 37-year-old weight lifter. Am Heart J. 1992;124(2):507-8.

161. Lau DH, Stiles MK, John B, Shashidhar, Young GD, Sanders P. Atrial fibrillation and anabolic steroid abuse. Int J Cardiol. 2007;117(2):e86-7.

162. Mewis C, Spyridopoulos I, Kuhlkamp V, Seipel L. Manifestation of severe coronary heart disease after anabolic drug abuse. Clin Cardiol. 1996; 19(2):153-5

163. Ment J, Ludman PF. Coronary thrombus in a 23 year old anabolic steroid user. Heart. 2002;88(4):342.

164. Ahlgrim C, Guglin M. Anabolics and Cardiomyopathy in a bodybuilder: case report and literature review. J Card Fail. 2009;15(6):496-500.

165. Joseph J, Naqvi S, Sturm E. Reversible anabolic androgenic steroid-induced cardiomyopathy. Cardiovasc Disord Med. 2017;2(3):1-3.

166. Nieminen MS, Ramo MP, Viitasalo M, Heikkila P, Karjalainen J, Mantysaari M, et al. Serious cardiovascular side effects of large doses of anabolic steroids in weight lifters. Eur Heart J. 1996;17(10):1576-83.

167. Stannard JP, Bucknell AL. Rupture of the triceps tendon associated with steroid injections. Am J Sports Med. 1993;21(3):482-5.

168. Farkash U, Shabshin N, Pritsch M. Rhabdomyolysis of the deltoid muscle in a bodybuilder using anabolic-androgenic steroids: a case report. J Athletic Train (National Athletic Trainers' Association). 2009:44(1):98-100.

169. Fenelon C, Dalton DM, Galbraith JG, Masterson EL. Synchronous quadriceps tendon rupture and unilateral $A C L$ tear in a weightlifter, associated with anabolic steroid use. BMJ Case Rep. 2016;2016

170. Bagherifard A, Jabalameli M, Rezazadeh J, Ghaffari S, Tabrizian P. Simultaneous bilateral quadriceps tendon rupture following a low - energy trauma in a male body builder with the history of anabolic - androgenic steroids consumption. Shafa Orthopedic J. 2018;5(2).

171. Liow RY, Tavares S. Bilateral rupture of the quadriceps tendon associated with anabolic steroids. British J Sports Med. 1995;29(2):77-9.

172. KramhØFt M, Solgaard S. Spontaneous rupture of the extensor pollicis longus tendon after anabolic steroids. J Hand Surg. 1986;11(1):87.

173. Tapaninen T, P V. Simultaneous bilateral rupture of the quadriceps tendon associated with anabolic steroids - a case report. Annals of Clinical Case Reports. 2016;1(1220).

174. David HG, Green JT, Grant AJ, Wilson CA. Simultaneous bilateral quadriceps rupture: a complication of anabolic steroid abuse. J Bone Joint Surgery British Volume. 1995:77(1):159-60.

175. Visuri T, Lindholm H. Bilateral distal biceps tendon avulsions with use of anabolic steroids. Med Sci Sports Exerc. 1994:26(8):941-4.

176. Freeman BJ, Rooker GD. Spontaneous rupture of the anterior cruciate ligament after anabolic steroids. Br J Sports Med. 1995;29(4):274-5.

177. Adamson R, Rambaran C, D'Cruz DP. Anabolic steroid-induced rhabdomyolysis. Hospital Med (London, England: 1998). 2005;66(6):362.

178. Erturan G, Davies N, Williams H, Deo S. Bilateral simultaneous traumatic upper arm compartment syndromes associated with anabolic steroids. J Emerg Med. 2013;44(1):89-91.

179. Leopardi P, Vico G, Rosa D, Cigala F, Maffulli N. Reconstruction of a chronic quadriceps tendon tear in a body builder. Knee Surg Sports Traumatol Arthrosc. 2006;14(10):1007-11.

180. Rich JD, Dickinson BP, Flanigan TP, Valone SE. Abscess related to anabolicandrogenic steroid injection. Med Sci Sports Exerc. 1999;31(2):207-9.

181. Friedman $O$, Arad E, Ben AO. Body builder's nightmare: black market steroid injection gone wrong: a case report. Plastic Reconstructive Surgery Global Open. 2016:4(9):e1040.

182. Shiber JR. Pyomyositis due to anabolic steroid injection. J Emerg Med. 2013; 44(1):e69-70.

183. Evans NA. Local complications of self administered anabolic steroid injections. Br J Sports Med. 1997;31(4):349-50.

184. Tüzel E. Spontaneous corpus cavernosum abscess in a healthy man using long-term androgenic anabolic steroids. World J Mens Health. 2015;33(1):36-8
185. Grant S, Dearing J, Ghosh S, Collier A, Bal AM. Necrotizing myositis of the deltoid following intramuscular injection of anabolic steroid. Int J Infect Dis. 2010;14(9):e823-4

186. Marquis C, Maffulli N. Anabolic steroid related abscess - a risk worth taking? Injury Extra. 2006;37:451-4

187. Ray S, Masood A, Pickles J, Moumoulidis I. Severe laryngitis following chronic anabolic steroid abuse. J Laryngol Otol. 2008;122(3):230-2.

188. Maini AAN, Maxwell-Scott H, Marks DJB. Severe alkalosis and hypokalemia with stanozolol misuse. Am J Emerg Med. 2014;32(2):196.e3-4.

189. Labib M, Haddon A. The Adverse effects of anabolic steroids on serum lipids. Ann Clin Biochem. 1996;33(3):263-4.

190. Cooper I, Reeve N, Doherty W. Delayed diagnosis of a cerebrovascular accident associated with anabolic steroid use. BMJ Case Rep. 2011;2011.

191. Unai S, Miessau J, Karbowski P, Baram M, Cavarocchi NC, Hirose H. Caution for anabolic androgenic steroid use: a case report of multiple organ dysfunction syndrome. Respiratory Care. 2013;58(12):e159-63.

192. Geraci MJ, Cole M, Davis P. New onset diabetes associated with bovine growth hormone and testosterone abuse in a young body builder. Hum Exp Toxicol. 2011:30(12):2007-12.

193. Alaraj AM, Chamoun RB, Dahdaleh NS, Haddad GF, Comair YG. Spontaneous subdural haematoma in anabolic steroids dependent weight lifters: reports of two cases and review of literature. Acta Neurochir (Wien). 2005;147(1):85-7 discussion 7-8.

194. Moor JW, Khan MI. Growth hormone abuse and bodybuilding as aetiological factors in the development of bilateral internal laryngocoeles. a case report. Eur Arch Otorhinolaryngol. 2005;262(7):570-2.

195. Tan RS, Scally MC. Anabolic steroid-induced hypogonadism - towards a unified hypothesis of anabolic steroid action. Med Hypotheses. 2009;72(6):723-8.

196. Kanayama G, Hudson Jl, Pope HG. Long-term psychiatric and medical consequences of anabolic-androgenic steroid abuse: a looming public health concern? Drug Alcohol Depend. 2008;98(1):1-12.

197. Kanayama G, Hudson JI, DeLuca J, Isaacs S, Baggish A, Weiner R, et al. Prolonged hypogonadism in males following withdrawal from anabolicandrogenic steroids: an under-recognized problem. Addiction (Abingdon, England). 2015;110(5):823-31

198. de Souza GL, Hallak J. Anabolic steroids and male infertility: a comprehensive review. BJU Int. 2011;108(11):1860-5.

199. Pope HG, Kanayama G, lonescu-Pioggia M, Hudson Jl. Anabolic steroid users' attitudes towards physicians. Addiction. 2004;99(9):1189-94.

200. Hope VD, McVeigh J, Marongiu A, Evans-Brown M, Smith J, Kimergard A et al. Injection site infections and injuries in men who inject image- and performance-enhancing drugs: prevalence, risks factors, and healthcare seeking. Epidemiol Infection. 2015;143(1):132-40

201. Bates G, McVeigh J. Image and performance enhancing drugs - 2015 survey results. Liverpool: Centre for Public Health; 2016.

202. Brooks JHM, Ahmad I, Easton G. 10-minute consultation anabolic steroid use. Bmj-Brit Med J. 2016:355.

203. Kanayama G, Boynes M, Hudson Jl, Field AE, Pope HG. Anabolic steroid abuse among teenage girls: an illusory problem? Drug Alcohol Depend. 2007;88(2-3):156-62

204. Korkia P, Lenehan P, McVeigh J. Non-medical use of androgens among women. J Perform Enhanc Drugs. 1996;1(2):71

205. Ip EJ, Barnett MJ, Tenerowicz MJ, Kim JA, Wei H, Perry PJ. Women and anabolic steroids: an analysis of a dozen users. Clin J Sport Med. 2010;20(6):475-81.

206. Hoberman J. Dopers in uniform: Police officers' use of anabolic steroids in the United States. In: Møller V, Waddington I, Hoberman JM, Møller V, Waddington I, Hoberman JM, editors. Routledge handbook of drugs and sport. New York, NY, US: Routledge/Taylor \& Francis Group; 2015. p. 439-52.

207. Turvey BE, Crowder S. Anabolic steroid abuse in public safety personnel: a forensic manual. San Diego: Academic Press; 2015.

208. Humphrey KR, Decker KP, Goldberg L, G. PH, Green GA. Anabolic steroid use and abuse by police officers: policy \& prevention. The Police Chief. 2008; LXXV.

209. Waterhouse J. Rise in soldiers testing positive for steroid use. Newsbeat [Internet]. 2014 25/3/2019.

210. Bolding G, Sherr L, Maguire $M$, Elford J. HIV risk behaviours among gay men who use anabolic steroids. Addiction (Abingdon, England). 1999;94(12): 1829-35.

211. Bolding G, Sherr L, Elford J. Use of anabolic steroids and associated health risks among gay men attending London gyms. Addiction. 2002; 97(2):195-203. 
212. Cornford CS, Kean J, Nash A. Anabolic-androgenic steroids and heroin use: a qualitative study exploring the connection. Int J Drug Policy. 2014;25(5): 928-30.

213. Kanayama G, Pope HG, Hudson JI. Associations of anabolic-androgenic steroid use with other behavioral disorders: an analysis using directed acyclic graphs. Psychol Med. 2018:1-8.

214. Salinas M, Floodgate W, Ralphs R. Polydrug use and polydrug markets amongst image and performance enhancing drug users: Implications for harm reduction interventions and drug policy. Int J Drug Policy. 2019;67:43-51.

215. Kimergard A. A qualitative study of anabolic steroid use amongst gym users in the United Kingdom: motives, beliefs and experiences. J Subst Use. 2015; 20(4):288-94.

216. Taylor WN. Anabolic steroids and the athlete. 2 ed. Jefferson, NC: MacFarland and Company Inc. Publishers; 2001.

217. Pampel FC. Drugs and Sport. New York: Facts on File; 2007.

\section{Publisher's Note}

Springer Nature remains neutral with regard to jurisdictional claims in published maps and institutional affiliations.

Ready to submit your research? Choose BMC and benefit from:

- fast, convenient online submission

- thorough peer review by experienced researchers in your field

- rapid publication on acceptance

- support for research data, including large and complex data types

- gold Open Access which fosters wider collaboration and increased citations

- maximum visibility for your research: over $100 \mathrm{M}$ website views per year

At BMC, research is always in progress.

Learn more biomedcentral.com/submissions 